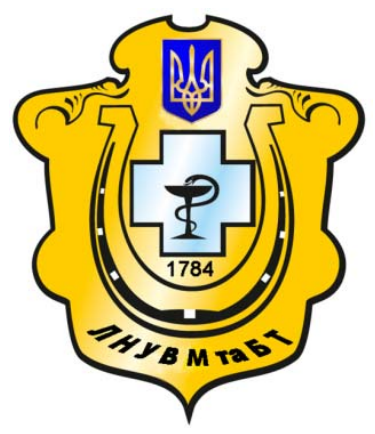

Науковий вісник Львівського національного університету ветеринарної медицини та біотехнологій імені С.3. Гжицького

Scientific Messenger of Lviv National University of Veterinary Medicine and Biotechnologies named after S.Z. Gzhytskyj

doi:10.15421/nvlvet7122

ISSN 2413-5550 print

ISSN 2518-1327 online

http://nvlvet.com.ua/

УДК 619:616.2:616.07:616.1/4:632.2

\title{
Бронхопневмонія телят: діагностика та комплексна терапія
}

\author{
Л.Г. Слівінська ${ }^{1}$, С.К. Демидюк ${ }^{1}$, А.Р. Щербатий ${ }^{1}$, П.С. Мазурок ${ }^{2}$ \\ ua-andrea@ukr.net \\ ${ }^{1}$ Львівський національний університет ветеринарної медицини та біотехнологій імені С.3. Гжсицького, \\ вул. Пекарська, 50, м. Львів, 79010, Украӥна; \\ ${ }^{2}$ Мирогощианський аграрний коледж, \\ вул. Студентська 1, с.Мирогощуа, Дубенський р-н, Рівненська обл, 35624, Україна
}

\begin{abstract}
У статті наведені результати показників неспецифічної резистентності, гематологічного та біохімічного досліджень за комплексного лікування телят, хворих бронхопневмонією. Встановлено, що застосування антибіотиків (інтраміцину, цефатоксиму $і$ бетамоксу LA), препаратів, які регулюють кислотно-лужний стан, забезпечують терапевтичну ефективність відповідно на 75, 88 і 94\% та скорочують термін їх лікування до 7 - 12 днів. Лікування позитивно вплинуло на загальний стан тварин. У крові встановили вірогідне збільшення кількості еритроцитів відповідно на 23,2\% ( $<<0,001)$; 36,6 ( $<<0,001) ; 29,5 \%$ ( $p<0,05)$, умісту гемоглобіну на 8,04 ( $<<0,05) ; 17,3(p<0,001)$ та 17,5\% $(p<0,001)$, зменшення кількості лейкоцитів ( $p$ <,001) відповідно на 31,8; 34,3; 36,6\%. Вміст загального білка у сироватиі крові телят у дослідних групах зростав на 3,75 ( $<<0,001) ; 6,38(p<0,05)$ i 6,93\% $(p<0,001)$ відповідно за рахунок збільшення фрракиії альбумінів у другій дослідній групі на 18,4\% (p<0,001), в третій - на 14,8\% (p<0,01). Результати досліджень показали, щзо застосоване лікування позитивно вплинуло на вміст каротину у сироватиі крові (на 43,5; 34,6; 46,0\%; $p<0,05)$, загального кальцію (відповідно на 15,0; 14,7; $p<0,05) ; 18,3 \%$; $p<0,05)$ та неорганічного фосфору (на 6,4; 15,3; 15,8\%; $p<0,05$ ).

Комплексне лікування телят, хворих катаральною бронхопневмонією, сприяло підвищенню показників неспецифічної резистентності. Отримані дані в результаті застосування антибіотиків (інтраміцину, цефатоксиму і бетамоксу LA) сприяли швидшій нормалізаиії лізоиимної та бактерииидної активності крові. Так, у першій дослідній групі ЛАСК збільшилась на 25,6\% ( $<<0,001)$; в другій - 26,3\% ( $<<0,001)$, в третій - 35,3\% $(p<0,001)$. БАСК у телят мала тенденцію до збільшення відповідно на 11,7; 10,6 і 11,3\%.
\end{abstract}

Ключові слова: бронхопневмонія, телята, неспецифічна резистентність, білки сироватки крові, інтраміцин, цефотаксим, бетамокс LA, гематологія, комплексна терапія, каротин, загальний кальиій, неорганічний фосфор.

\section{Бронхопневмония телят: диагностика и комплексная терапия}

\author{
Л.Г. Сливинская ${ }^{1}$, С.К. Демидюк ${ }^{1}$, А.Р. Щербатый ${ }^{1}$, П.С. Мазурок ${ }^{2}$ \\ ua-andrea@ukr.net
}

\footnotetext{
${ }^{1}$ Львовский национальный университет ветеринарной медиџины и биотехнологий имени С.3. Гжиџкого, ул. Пекарская, 50, г. Львов, 79010, Украина;

${ }^{2}$ Мирогошанский аграрный колледж,

ул. Студенческая 1, с.Мирогоща, Дубенский р-н, Ривненская обл, 35624, Украина
}

\begin{abstract}
В статье приведены результаты показателей неспецифической резистентности, гематологического, биохимического исследований при комплексном лечении телят, больных бронхопневмонией. Установлено, что применение антибиотиков (интрамицину, цефатоксиму и бетамоксу LA), препаратов, которые регулируют кислотно-щелочное состояние, обеспечивают терапевтическую эффективность соответственно на 75, 94 и 88\% и укорачивают срок их лечения до $7-12$ дней. Лечение положительно влияло на общее состояние животных. В крови установили достоверное увеличение количества эритрочитов соответственно на 23,2\% (p<0,001) 36,6 $(p<0,001)$ 29,5\% $(p<0,05)$, содержание гемоглобина на 8,04
\end{abstract}

Citation:

Slivinska, L., Demydjuk, S., Shcherbatyy, A., Mazurok, P. (2016). Bronchopneumonia of calves: diagnosis and complex therapy. Scientific Messenger LNUVMBT named after S.Z. Gzhytskyj, 18, 3(71), 95-99. 
( $p<0,05) 17,3(p<0,001)$ и 17,5\% ( $p<0,001)$, уменьшение количества лейкоцитов $(p<0,001)$ соответственно на 31,8 ; 34,3; 36,6\%. Содержание общего белка в сыворотке крови телят в опытных группах вирос на 3,75 (p < 0,001) 6,38 $(p<0,05)$ и 6,93\% ( $<$ < 0,001) соответственно за счет увеличения фракции альбуминов во второй опытной группе на $18,4 \%$ ( $p<0,001)$, в третьей - на 14,8\% ( $p<0,01)$. Результаты исследований показали, что примененное лечение положительно влияло на содержание каротина в сыворотке крови (на 43,5; 34,6; 46,0\%; $p<0,05$ ), общего кальция (соответственно на $15,0 ; 14,7 ; p<0,05 ; 18,3 \% ; p<0,05)$ и неорганического фосфора (на 6,4; 15,3; 15,8\%; $<<0,05)$.

Комплексное лечение телят, больных катаральной бронхопневмонией, способствовало повышению показателей неспеиифической резистентности. Полученные данные в результате применения антибиотиков (интрамицину, цефатоксиму и бетамоксу LA) способствовали быстрой нормализачии лизочимнои и бактерицидной активности крови. Так, в первой опытной группе ЛАСК увеличилась на 25,6\% (p < 0,001) во второй - на 26,3\% (p < 0,001) и в третий на 35,3\% (p<0,001). БАСК у телят била тенденцию к увеличению соответственно на 11,7; 10,6 и 11,3\%.

Ключевые слова: бронхопневмония, телята, неспецифическая резистентность, белки сыворотки крови, интрамицин, цефотаксим, бетамокс LA, гематология, комплексная терапия, каротин, общий кальций, неорганический фосфор.

\title{
Bronchopneumonia of calves: diagnosis and complex therapy
}

\author{
L. Slivinska ${ }^{1}$, S. Demydjuk ${ }^{1}$, A. Shcherbatyy ${ }^{1}$, P. Mazurok ${ }^{2}$ \\ ua-andrea@ukr.net \\ ${ }^{1}$ Lviv National University of Veterinary Medicine and Biotechnologies named after S.Z. Gzhytskyi, \\ Pekarska Str., 50, Lviv, 79010, Ukraine; \\ ${ }^{2}$ Myrohoschanskyy Agricultural College \\ Studencheskaya Str., 1, Myrohoscha, Dubno district, Rivne region, 35624, Ukraine
}

The results of nonspecific resistance indices, hematological, biochemical research on complex treatment of calves suffering from bronchopneumonia. It is established that the use of antibiotics (intramitsynu, tsefatoksymu and betamoksu LA), drugs that regulate the acid-base status, provide therapeutic efficacy, respectively - 75, 94 and 88\% and shorten the duration of their treatment in 7 12 days. The treatment had a positive impact on the overall condition of the animals. In the blood have established probable increase in the number of red blood cells, respectively, $23.2 \%(p<0.001) ; 36.6(p<0.001) ; 29.5 \%(p<0.05)$, hemoglobin contents to $8.04(p<0.05) ; 17.3(p<0.001)$ and $17.5 \%(p<0.001)$, reducing the number of leukocytes $(p<0.001)$ according to 31.8; 34.3 ; $36.6 \%$. The content of total protein in serum of calves experimental groups increased to $3.75(p<0,001) ; 6.38(p<0.05)$ and $6.93 \%$ $(p<0.001)$, respectively, due to increased albumin fraction in the second experimental group $18.4 \%(p<0.001)$, the third $-14.8 \%$ $(p<0,01)$. The results showed that the applied treatment had a positive impact on the carotene content in blood serum (to 43.5; 34.6; 46.0\%; $p<0.05)$, total calcium (respectively 15.0, 14.7; $p<0.05 ; 18.3 \% ; p<0.05)$ and inorganic phosphorus (6.4; 15.3; $15.8 \% ; p<0.05)$.

Integrated treatment of calves suffering from bluetongue bronchopneumonia, helped indexes increase non-specific resistance. The data obtained by the use of antibiotics (intramitsynu, tsefatoksymu and betamoksu LA) promoted faster normalization lizotsymnoyi and bactericidal activity of blood. Thus, in the first experimental group LASK increased by $25.6 \%(p<0.001)$; the second-by $26.3 \%(p<0.001)$ and the third at $35.3 \%(p<0.001)$. BASK calves tended to increase according to $11.7 ; 10.6$ and $11.3 \%$.

Key words: pneumonia, calves, nonspecific resistance, serum proteins, intramitsyn, cefotaxime, betamoks LA, hematology, complex therapy, carotene, total calcium, inorganic phosphorus.

\section{Ветуп}

Бронхопневмонія молодняку худоби займає одне із провідних місць серед незаразної патології тварин і залишається важливою проблемою ветеринарної медицини. На відміну від інфекційних і паразитарних хвороб, безпосередньою причиною виникнення яких $\epsilon$ специфічні збудники (бактерії, віруси, рикетсії, паразити та інші біотичні фактори), в етіології внутрішніх неінфекційних хвороб вирішальне значення має поєднання декількох внутрішніх та зовнішніх, частіше абіотичних факторів, що негативно впливають на організм: неповноцінна і неякісна годівля, протяги, перегрівання або переохолодження, антисанітарне утримання (Masljanko, 1987; Bajmatov and Mingazov, 2005). Сприяє цьому низька неспецифічна резистентність та імунна реактивність організму телят, яка зумовлена порушенням технології утримання, годівлі, різних ланок метаболізму, розвитком вікового і набутого імунодефіциту (Stadnyk et al., 2003). Раннє виявлення клінічних ознак хвороби (підвищення температури тіла, тахікардія, тахіпное, наявність вогнищ при- туплення, витікання серозно-катарального ексудату 3 носа) в більшості випадків визначає ефективність лікування (Bobylev et al., 2000; Lochkarev, 2000; Apatenko and Dorogobit, 2001; Gadzaonov, 2003; Gavrysh, 2004). Лікування тварин має бути комплексним і включати: нормування годівлі, догляду, умов утримання, підвищення імунного статусу, застосування раціональної терапії (патогенетична, етіотропна, симптоматична), 3 урахуванням особливостей перебігу хвороби та загального стану тварини (Sorden et al., 2000; Matjushev and Samarina, 2001; Porfir'ev, 2007; Srikumaran et al., 2008).

Виходячи 3 цього, метою роботи було визначити ефективність комплексної терапії з використанням антибіотиків (інтраміцину, цефотаксиму та бетамоксу LA) та обгрунтувати їх терапевтичне застосування за бронхопневмонії телят.

\section{Матеріал і методи досліджень}

Дослідження проводили на базі СВК імені Лесі Українки Дубенського району Рівненської області та 
державного підприємства Мирогощанського державного іподрому Дубенського району Рівненської області. Матеріалом для дослідження була кров хворих тварин. Досліджували телят чорно-рябої породи віком $2-3$ місяці, хворих на катаральну бронхопневмонію.

Тварин відібрали за принципом аналогів і поділено на 3 групи (1, 2, 3 дослідна). Телят першої дослідної групи лікували за методикою господарств з використанням інтраміцину в дозі 0,8 мл на кг маси тіла 1 раз на добу та задаванням сульфадимезину в дозі 2 г в день внутрішньо. Із симптоматичних засобів застосовували кофеїн бензоат натрію внутрішньо 2 г -2 рази на добу і відхаркуючі - амонію хлорид 5,0 - 2 рази на добу. Телятам другої дослідної групи використовували антибіотик цефотаксим в дозі 500 мг внутрім'язево 2 рази на добу. Цефотаксим натрієва сіль - напівсинтетичний антибіотик з групи цефалоспоринів третього покоління. Препарат має широкий спектр бактерицидної дії, активний проти грампозитивних і грамнегативних бактерій. Крім цього застосовували симптоматичну терапію (відхаркуючі - амонію хлорид внутрішньо, серцеві - кофеїн бензоат натрію внутрішньо два рази на добу, неспецифічну терапію - неспецифічний гамма-глобулін в дозі 0,5 мл/кг маси тіла п/ш 1 раз на 48 годин). Телятам третьої дослідної групи вводили бетамокс LA, який належить до бета-лактанових антибіотиків і відзначається високою бактерицидною дією. Препарат активний проти грампозитивних i грамнегативних бактерій. Його вводили в дозі 1 мл/10 кг маси тіла 1 раз на добу. Симптоматичне лікування: тривітамін в/м 5 мл 1 раз на 3 доби, в/в вводили глюкозу - гідрокарбонатну суміш 3 розрахунку 1 мл/кг маси тіла в такому складі: 5 г глюкози, 6,5 г натрію гідрокарбонату, 4,5 г натрію хлориду, розчинених в 1 л дистильованої води, розчин не кип'ятили.

Кров для досліджень брали перед початком лікування та на 7-й день. У крові визначали кількість лейкоцитів, еритроцитів, рівень гемоглобіну - на гематологічному аналізаторі Mythic 18. У сироватці крові - вміст загального білка, неорганічного фосфору та загального кальцію - на біохімічному аналізатоpi Mindray BS - 120; співвідношення окремих білкових фракцій методом електрофорезу на ацетат - целюлозних пластинках; бактерицидну активність сироватки крові (БАСК) - нефелометричним методом 3 використанням бульйону Хотінгера за Манселем i Трефенсом в модифікації О.В.Смірнової та Т.А.Кузміної (1971); лізоцимну активність - фотоколориметричним методом в модифікації відділу зоогігієни УНДІЕВ 3 тест культурою $M$. lysodecticus (Masljanko, 1987).

Отримані результати експериментальних досліджень обробляли методом варіаційної статистики 3 використанням спеціального програмного забезпечення (програма «Statistika»). Вірогідність показників $(\mathrm{p}<0,05, \mathrm{p}<0,01, \mathrm{p}<0,001)$ оцінювали за критерієм Стьюдента.

Лікувальну ефективність препарату визначали за клінічними параметрами, аналізом лабораторних досліджень крові.

\section{Результати та їх обговорення}

Діагноз на катаральну бронхопневмонію телят ставили на основі даних анамнезу, клінічних симптомів, аналізу епізоотичної ситуації в господарствах та лабораторних досліджень крові. У хворих тварин спостерігали пригнічений загальний стан, зниження апетиту, серозно-катаральні виділення із носової порожнини, кашель, тахіпное (62 дих.рух./хв.), тахікардію (90 уд./хв.) та підвищення загальної температури тіла $\left(40,2^{\circ} \mathrm{C}\right)$.

По закінченню проведеного досліду (через 10 днів від початку введення терапевтичних препаратів) у телят дослідних груп температура тіла становила 39,2 $\pm 0,03{ }^{\circ} \mathrm{C} ; 39,2 \pm 0,03{ }^{\circ} \mathrm{C}$ та $39,1 \pm 0,06{ }^{\circ} \mathrm{C}$; частота пульсу $-76,0 \pm 1,6 ; 76,4 \pm 1,4$ i 75,2 $\pm 1,2$ уд./хв. та частота дихання $34,6 \pm 1,6 ; 31,4 \pm 1,2$ i $34,2 \pm 2,1$ дих.рух./хв.

Гематологічні та біохімічні показники крові телят $(\mathrm{M} \pm \mathbf{m}, \mathbf{n}=\mathbf{2 4})$

\begin{tabular}{|c|c|c|c|c|c|c|c|}
\hline \multirow{4}{*}{ Показники } & \multicolumn{6}{|c|}{ Групи тварин } & \multirow{4}{*}{$\begin{array}{c}\text { Клінічно } \\
\text { здорові } \\
\text { телята }\end{array}$} \\
\hline & \multicolumn{2}{|c|}{1 дослідна } & \multicolumn{2}{|c|}{2 дослідна } & \multicolumn{2}{|c|}{3 дослідна } & \\
\hline & \multicolumn{6}{|c|}{ Лікування } & \\
\hline & до & після & до & після & до & після & \\
\hline $\begin{array}{c}\text { Гемоглобін, г/л } \\
\mathrm{p}<\end{array}$ & $91,4 \pm 2,10$ & $\begin{array}{c}99,4 \pm 2,24 \\
0,05\end{array}$ & $89,6 \pm 2,22$ & $\begin{array}{c}108,4 \pm 2,12 \\
0,001\end{array}$ & $90,8 \pm 2,21$ & $\begin{array}{c}110,0 \pm 2,64 \\
0,001\end{array}$ & $112,0 \pm 2,14$ \\
\hline $\begin{array}{c}\text { Еритроцити, T/л } \\
\mathrm{p}<\end{array}$ & $4,3 \pm 0,21$ & $\begin{array}{c}5,3 \pm 0,04 \\
0,001\end{array}$ & $4,1 \pm 0,22$ & $\begin{array}{c}5,6 \pm 0,24 \\
0,001 \\
\end{array}$ & $4,4 \pm 0,36$ & $\begin{array}{c}5,7 \pm 0,34 \\
0,05 \\
\end{array}$ & $5,8 \pm 0,28$ \\
\hline $\begin{array}{c}\text { Лейкоцити, Г/л } \\
\mathrm{p}<\end{array}$ & $13,2 \pm 0,32$ & $\begin{array}{c}9,0 \pm 0,14 \\
0,001\end{array}$ & $14,0 \pm 0,26$ & $\begin{array}{c}9,2 \pm 0,16 \\
0,001\end{array}$ & $14,2 \pm 0,34$ & $\begin{array}{c}9,0 \pm 0,20 \\
0,001\end{array}$ & $7,2 \pm 0,20$ \\
\hline $\begin{array}{c}\text { Каротин, } \\
\text { мкмоль/л } \\
\text { p }<\end{array}$ & $0,46 \pm 0,02$ & $0,66 \pm 0,14$ & $0,52 \pm 0,16$ & $0,70 \pm 0,18$ & $0,50 \pm 0,07$ & $\begin{array}{c}0,73 \pm 0,06 \\
0,05\end{array}$ & $0,85 \pm 0,05$ \\
\hline $\begin{array}{c}\text { Загальний каль- } \\
\text { цій, ммоль/л } \\
\text { р< }\end{array}$ & $2,26 \pm 0,22$ & $2,66 \pm 0,20$ & $2,32 \pm 0,16$ & $\begin{array}{l}2,72 \pm 0,13 \\
0,05\end{array}$ & $2,27 \pm 0,22$ & $\begin{array}{l}2,78 \pm 0,08 \\
0,05\end{array}$ & $2,84 \pm 0,16$ \\
\hline $\begin{array}{c}\text { Неорганічний } \\
\text { фосфор, ммоль/л } \\
\text { p }<\end{array}$ & $1,76 \pm 0,20$ & $1,88 \pm 0,07$ & $1,66 \pm 0,15$ & $1,96 \pm 0,14$ & $1,70 \pm 0,12$ & $\begin{array}{c}2,02 \pm 0,12 \\
0,05\end{array}$ & $2,12 \pm 0,14$ \\
\hline
\end{tabular}

Примітки: $\mathbf{p}<0,05 ; 0,001$ - порівняно з початком лікування 
Застосоване лікування сприяло збільшенню кількості виділень із носових отворів у телят, вони ставали більш рідкими, набували серозного характеру.

Окрім того, кількість еритроцитів у крові хворих телят дослідних груп вірогідно (p < 0,001) зменшувалася на 23,$3 ; 36,6 ; 29,5 \%$ порівняно з клінічно здоровими телятами (табл. 1).

Рівень гемоглобіну у крові телят 1 дослідної групи становив 91,4 $\pm 2,10$; другої $-89,6 \pm 2,22$ і третьої $90,8 \pm 2,21$ г/л. У хворих телят розвивався лейкоцитоз $(13,2 \pm 0,32 ; 14,0 \pm 0,26 ; 14,2 \pm 0,34$ Г/л).

Біохімічні показники крові характеризувалися зменшеним вмістом каротину на 84,$7 ; 63,5 ; 70,0 \%$ ( $<<0,001)$, загального кальцію на 25,$7 ; 22,4 ; 25,1 \%$ $(\mathrm{p}<0,001)$, неорганічного фосфору на 25,$0 ; 27,7$; $24,7 \%(\mathrm{p}<0,001)$, загального білка на 10,$1 ; 10,8 ; 8,3 \%$ ( $<<0,001)$, альбумінів на 25,5; 21,7; 19,4\% (p < 0,001) (табл. 2), бактерицидної активності на 17,3; 15,6;
$15,1 \%(\mathrm{p}<0,001)$ і лізоцимної активності у 2,1; 2,2; 2,4 рази (табл. 3) відповідно в 1, 2, 3 групах порівняно 3 клінічно здоровими тваринами.

Аналізуючи дані таблиці 2 слід відмітити, що вміст загального білка у дослідних групах зріс на 3,75 $(\mathrm{p}<0,001) ; 6,38(\mathrm{p}<0,05)$ і 6,93\% (p < 0,001) відповідно.

Терапевтичний ефект антибактеріальних препаратів сприяв послабленню запального процесу в легеневій тканині, внаслідок чого кількість альбумінів у другій дослідній групі вірогідно ( $<0,001)$ збільшилась на $18,4 \%$, в третій дослідній групі на 14,8\% $(\mathrm{p}<0,01)$.

Крім цього, у телят дослідних груп відмічали збільшення кількості $\alpha$-глобулінів на 8,0 \% в першій дослідній групі; на $17,0 \%(\mathrm{p}<0,001)$ в другій, на $12,3 \%(\mathrm{p}<0,001)$ в третій.

Таблиия 2

Концентрація загального білка та процент білкових фракцій сироватки крові телят (M $\pm \mathbf{m}, \mathbf{n}=\mathbf{2 4})$

\begin{tabular}{|c|c|c|c|c|c|c|c|}
\hline \multirow{4}{*}{ Показники } & \multicolumn{6}{|c|}{ Групи тварин } & \multirow{4}{*}{$\begin{array}{c}\text { Клінічно } \\
\text { здорові } \\
\text { телята }\end{array}$} \\
\hline & \multicolumn{2}{|c|}{1 дослідна } & \multicolumn{2}{|c|}{2 дослідна } & \multicolumn{2}{|c|}{3 дослідна } & \\
\hline & & & Лік & ання & & & \\
\hline & до & після & до & після & до & після & \\
\hline $\begin{array}{c}\text { Загальний білок, } \\
\text { г/л } \\
\mathrm{p}<\end{array}$ & $65,2 \pm 0,25$ & $\begin{array}{c}67,7 \pm 0,27 \\
0,001\end{array}$ & $64,8 \pm 0,60$ & $\begin{array}{c}69,2 \pm 1,50 \\
0,05\end{array}$ & $66,3 \pm 0,46$ & $\begin{array}{c}71,2 \pm 0,34 \\
0,001\end{array}$ & $71,8 \pm 1,02$ \\
\hline $\begin{array}{c}\text { Альбуміни, \% } \\
\text { p }<\end{array}$ & $35,3 \pm 0,40$ & $\begin{array}{c}37,8 \pm 1,30 \\
0,05\end{array}$ & $36,4 \pm 0,54$ & $\begin{array}{c}43,1 \pm 1,24 \\
0,001\end{array}$ & $37,1 \pm 0,57$ & $\begin{array}{c}42,6 \pm 1,44 \\
0,001\end{array}$ & $44,3 \pm 2,16$ \\
\hline $\begin{array}{c}\alpha-\text {-гобуліни, } \\
\% \\
\text { p }<\end{array}$ & $16,3 \pm 0,62$ & $17,6 \pm 0,70$ & $14,7 \pm 0,29$ & $\begin{array}{c}17,2 \pm 0,35 \\
0,001\end{array}$ & $16,2 \pm 0,26$ & $\begin{array}{c}18,2 \pm 0,22 \\
0,001\end{array}$ & $16,1 \pm 0,30$ \\
\hline $\begin{array}{c}\beta-\text {-глобуліни, \% } \\
\mathrm{p}<\end{array}$ & $18,2 \pm 0,46$ & $\begin{array}{c}16,2 \pm 0,10 \\
0,001\end{array}$ & $19,6 \pm 0,51$ & $\begin{array}{c}15,9 \pm 0,42 \\
0,001\end{array}$ & $19,2 \pm 0,45$ & $\begin{array}{c}15,3 \pm 0,53 \\
0,001\end{array}$ & $15,1 \pm 0,64$ \\
\hline $\begin{array}{c}\gamma-\text { глобуліни, \% } \\
\text { p }<\end{array}$ & $29,2 \pm 1,40$ & $27,2 \pm 0,12$ & $27,2 \pm 1,36$ & $\begin{array}{c}22,2 \pm 0,90 \\
0,01\end{array}$ & $25,9 \pm 1,20$ & $23,6 \pm 0,84$ & $24,7 \pm 1,42$ \\
\hline
\end{tabular}

Примітки: $\mathrm{p}<0,05 ; 0,001$ - порівняно 3 початком лікування

Табличя 3

Показники неспецифічної резистентності у телят $(\mathrm{M} \pm \mathbf{m}, \mathbf{n}=\mathbf{2 4})$

\begin{tabular}{|c|c|c|c|c|c|c|c|}
\hline \multirow{4}{*}{ Показники } & \multicolumn{6}{|c|}{ Групи тварин } & \multirow{4}{*}{$\begin{array}{c}\text { Клінічно } \\
\text { здорові } \\
\text { телята }\end{array}$} \\
\hline & \multicolumn{2}{|c|}{1 дослідна } & \multicolumn{2}{|c|}{2 дослідна } & \multicolumn{2}{|c|}{3 дослідна } & \\
\hline & \multicolumn{6}{|c|}{ Лікування } & \\
\hline & до & після & до & після & до & після & \\
\hline $\begin{array}{l}\text { Бактерицидна } \\
\text { активність, \% } \\
\text { p < }\end{array}$ & $41,6 \pm 2,60$ & $47,1 \pm 3,65$ & $42,2 \pm 4,20$ & $47,2 \pm 3,64$ & $42,4 \pm 3,68$ & $47,8 \pm 4,11$ & $48,8 \pm 2,44$ \\
\hline $\begin{array}{c}\text { Лізоцимна актив- } \\
\text { ність, \% } \\
\text { p }<\end{array}$ & $12,8 \pm 0,22$ & $\begin{array}{l}17,2 \pm 0,26 \\
0,001\end{array}$ & $12,6 \pm 0,21$ & $\begin{array}{l}17,1 \pm 0,28 \\
0,001\end{array}$ & $11,6 \pm 0,20$ & $\begin{array}{l}17,9 \pm 0,29 \\
0,001\end{array}$ & $27,5 \pm 0,40$ \\
\hline
\end{tabular}

Примітки: $\mathrm{p}<0,001$ - порівняно $з$ початком лікування

Характер зміни $\beta$-глобулінів мав тенденцію до вірогідного ( $<0,001)$ зниження у дослідних групах. Концентрація $\gamma$-глобулінів у трьох групах хворих тварин була вірогідно (p < 0,001) вищою на 15,4; 10,1; 4,8\% порівняно 3 клінічно здоровими телятами. Протягом проведеного лікування вміст їх знизився на 7,3; 22,5 (p < 0,01); 9,7\% відповідно у дослідних групах та наблизився до рівня клінічно здорових тварин $(24,7 \pm$ $1,42 \%)$.
Отже, зниження вмісту глобулінів в сироватці крові хворих катаральною бронхопневмонією телят, на нашу думку, була спричинена порушенням їх синтезом у печінці та підгострим респіраторним ацидозом $з$ наступним використанням цієї фракції білків в енергетичних і анаболічних процесах.

Після проведеного лікування у більшості тварин спостерігали відновлення апетиту, відсутність кашлю, носових витікань, нормалізацію частоти пульсу, ди- 
хання, температури тіла, зменшення і зникнення ділянок притуплення.

При проведенні гематологічних досліджень відмічено збільшення кількості еритроцитів відповідно на $23,2(\mathrm{p}<0,001) ; 36,6(\mathrm{p}<0,001) ; 29,5 \%(\mathrm{p}<0,05)$, а кількість лейкоцитів вірогідно $(\mathrm{p}<0,001)$ зменшилась на 31,$8 ; 34,3 ; 36,6 \%$. Уміст гемоглобіну після лікування збільшився на 8,04 (p < 0,05); 17,3 (р <0,001) та $17,5 \%(\mathrm{p}<0,001)$ порівняно з початком лікування.

Виявили позитивні зміни щодо вмісту каротину, який збільшився вірогідно на 43,5; 34,6; 46,0\% (p < $0,05)$, загального кальцію відповідно на 15,$0 ; 14,7$ (p < $0,05) ; 18,3 \%(\mathrm{p}<0,05)$, неорганічного фосфору на 6,4 ; 15,$3 ; 15,8 \%(\mathrm{p}<0,05)$.

Комплексне лікування телят, хворих катаральною бронхопневмонією, сприяло підвищенню показників неспецифічної резистентності, нормалізації білкового спектра крові. Отримані дані в результаті застосування антибіотиків (інтраміцину, цефатоксиму і бетамокcy LA) сприяли швидшій нормалізації лізоцимної та бактерицидної активності крові. Так, у першій дослідній групі ЛАСК вірогідно збільшилась на 25,6\% $(\mathrm{p}<0,001)$; в другій - на $26,3 \%(\mathrm{p}<0,001)$ та в третій на $35,3 \%(\mathrm{p}<0,001)$. БАСК у телят мала тенденцію до збільшення відповідно на 11,7; 10,6 і 11,3\%.

Таким чином, наведені дані вказують на те, що застосування комплексного лікування телят хворих на катаральну бронхопневмонію сприяє усуненню основних клінічних симптомів хвороби, поступового унормування показників неспецифічної резистентності, біохімічних показників сироватки крові та гемопоезу.

При лікуванні телят третьої дослідної групи, хворих катаральною бронхопневмонією, де в комплексній терапії використовували антибіотик бетамокс LA, повне клінічне одужання спостерігали на $7-8$ день від початку застосованого лікування у 94\% тварин. У телят другої дослідної групи, де використовували цефотаксим, клінічне одужання спостерігали на 8-9 день у 88\% тварин. У телят першої дослідної групи одужання наступало на 10 - 12 день у 75\% тварин.

\section{Висновки}

1. Катаральна бронхопневмонія, поряд з відповідними клінічними симптомами, характеризується еритропенією, лейкоцитозом зниженням вмісту гемоглобіну, загального білку, глобулінів, каротину, загального кальцію, неорганічного фосфору та неспецифічної резистентності. 2. Комплексна терапія телят хворих бронхопневмонією, із застосуванням антибіотиків інтраміцину, цефотаксиму та бетамоксу LA, симптоматичної та регулюючої кислотно-лужного стану терапії, забезпечує належний лікувальний ефект відповідно у 75, 88 та 94\% тварин, скорочує термін їх лікування, унормовує гематологічні та біохімічні показники, підвищує неспецифічну резистентність.

\section{Бібліографічні посилання}

Apatenko, V., Dorogobit, A. (2001). Likuvannja i profilaktyka pnevmoenterytiv teljat. Veterynarna medycyna Ukrai'ny. 3, 28 (in Ukrainian)

Masljanko, R.P. (1987). Immunologicheskie metody issledovanie $\mathrm{V}$ zhivotnovodstve (Metodicheskie rekomendacii). L'vov (in Russian).

Bajmatov, V.N., Mingazov, I.D. (2005). Nespecificheskaja rezistentnost' organizma teljat pri bronhite. Veterinarija. 6, 48 (in Russian).

Bobylev, G.M., Sattorov, I.T., Mahmudov, K. (2000). Immunostimulirujushhie prepararty pri bronhopnevmonii teljat. Veterinarija, 2000. 10, 41 (in Russian).

Gavrysh, A.G. (2004). Odyn iz metodiv pidvyshhennja zberezhennosti teljat. Veterynarna medycyna Ukrainy. 8, 28 (in Ukrainian)

Gadzaonov, R.H. (2003). Jeffektivnost' ajerozolja hlorofilipta pri nespecificheskoj bronhopnevmonii teljat. Veterinarija. 11, 39 (in Russian).

Lochkarev, V.A. (2000). Povyshenie jeffektivnosti lechenija pri bronhopnevmonii u teljat. 11, 38 (in Russian).

Matjushev, P.S, Samarina, M.N. (2001). Profilaktika bronhopnevmonii teljat immunostimuljatorami. Veterinarija. 9, 35 (in Russian).

Porfir'ev, I.A. (2007). Profilaktika nespecificheskoj bronhopnevmonii u teljat. Veterinarija. 1, 42-46 (in Russian).

Stadnyk, A.M. Demydjuk S.K., Terlec'kyj B.M. (2003). Patogenez, diagnostyka ta kompleksna terapija teljat, hvoryh na bronhopnevmoniju iz zastosuvannjam mikroelementiv. Visnyk Bilocerkiv. nac. agrar. untu. - Bila Cerkva, 2003. 25(3), 99-106 (in Ukrainian).

Sorden, S.D., Kerr, R.W., Janzen, E.D. (2000). Interstitial pneumonia in feedlot cattle: concurrent lesions and lack of immunohistochemical evidence for bovine respiratory syncytial virus infection. J Vet Diagn Invest. 12, 510-517.

Srikumaran, S, Kelling, C.L., Ambagala, A. (2008). Immune evasion by pathogens of bovine respiratory disease complex. Anim Health Res Rev. 8, 215-229.

Стаття надійшла до редакиї 5.09.2016 